\title{
Cross-cultural adaptation of the drug-taking confidence questionnaire drug version for use in Brazil
}

Selene Cordeiro Vasconcelos ${ }^{1 *}$, Everton Botelho Sougey², Iracema da Silva Frazão ${ }^{2}$, Nigel Ernest Turner ${ }^{3}$, Vânia Pinheiro Ramos ${ }^{2}$ and Murilo Duarte da Costa Lima ${ }^{2}$

\begin{abstract}
Background: The Drug-Taking Confidence Questionnaire evaluates a drug user's confidence in his or her ability to resist the urge to consume psychoactive substances in high-risk situations. This study's objective was to develop a cross-cultural adaptation of the eight-item version of the Drug-Taking Confidence Questionnaire (DTCQ-8) for all drugs except alcohol and to verify its content validity and reliability in a pre-test stage.

Methods: The following steps were taken: (1) implementation of the translation protocol and transcultural adaptation, (2) validation of the adapted content, and (3) assessment of reliability. Nine experts participated in the process of adaptation, and the trial's sample comprised 40 drug users in treatment at a Psychosocial Care Center for Alcohol and Other Drugs (CAPSad).

Results: The average indices of semantic agreement (0.989; 0.989; 1.00), idiomatic (0.967), experiential (0.956), conceptual (0.978) and content validity with respect to language clarity (0.972), practice relevance (0.958), theoretical relevance (0.958) and theoretical dimension (1.00) showed that the adaption was successful. The mean total score of the DTCQ-8 version for other drugs was $477.00+234.27-\mathrm{SD}$, and $57.5 \%$ of the users were classified as having moderate self-efficacy to resist the urge to use drugs in high-risk situations. The Cronbach's alpha coefficient was 0.889 for the complete instrument and 0.863-0.890 between items.
\end{abstract}

Conclusions: The DTCQ-8 version for other drugs proved to be easy to use and understand, and its process of adaptation was satisfactory for use in the Brazilian context. In this sample, the questionnaire was adequate to measure users' self-efficacy to resist the urge to consume these substances in high-risk situations.

Keywords: Self-efficacy, Nursing, Drug users, Mental health, Addiction, Cross-cultural adaptation, Instrument translation, Validation studies

\section{Background}

Abuse and drug addiction are major public health problems worldwide [1]. These problems are characterized by users' drug-seeking behavior, loss of pleasure in daily activities, and deterioration of social, work and family relationships [2,3]. The Brazilian government recognizes these issues and has been investing in programs to treat drug users as well as addressing the implications of this use [4].

\footnotetext{
* Correspondence: selumares@yahoo.com.br

${ }^{1}$ Federal University of Paraíba-UFPB, João Pessoa, Brazil

Full list of author information is available at the end of the article
}

Consumption of stimulating drugs, such as cocaine, smoked or snorted, is increasing in Brazil, whereas in other emerging countries it has been declining [5]. Approximately 5 million Brazilian adults have snorted cocaine at least once in their lifetime, and approximately 2 million said they had used it in the previous 12 months. In addition, 1.7 million Brazilian adults have used smoked cocaine (crack) at least once in their lifetime, and 800,000 used it in the previous 12 months [6]. Crack use has been associated with high mortality among users [7].

The prevalence of smokers in Brazil is $15.0 \%$ (21.9 million people); commercial cigarettes are the most 
commonly used tobacco product. Men constitute a higher percentage of users $(19.2 \%)$ than women (11.2\%), and the highest percentage of users (19.4\%) are $40-59$ years of age [8].

Among the many harmful effects of drug abuse, the most common are cognitive and behavioral changes [9-11] and impaired self-efficacy, which is the confidence in one's ability to organize and execute behaviors necessary to manage life $[12,13]$. Self-efficacy has been integrated into social cognitive theory [13], which is based on the agency for self-development, adaptation and change $[14,15]$.

Self-efficacy is the basis of various treatment strategies for drug abusers [16-18]. Validated instruments designed to measure a particular aspect of drug use to guide interventions in health care can contribute to the development of more appropriate strategies and alleviation of the losses due to the harmful use of drugs $[19,20]$.

Measurement of self-efficacy to resist the urge to consume psychoactive substances in high-risk situations has been related to outcomes and treatment prognosis for drug users as well as the rates of recovery from the problems arising from such consumption [21-24]. Therefore, a valid and reliable instrument to measure this self-efficacy is an important tool for planning and evaluating the health interventions in that population [24].

To assess this self-efficacy-that is, to assess drug users' trust in their ability to confront these situations-Annis and Martin (1985) [25] created the Inventory of Drug-Taking Situations. Later Sklar, Annis and Turner (1997) [26] developed the Drug-Taking Confidence Questionnaire. This version, which contained 50 items (DTCQ-50), was an explanatory guide [27], and its confirmed validity led to the release of the eight-item version (DTCQ-8) [28].

The DTCQ-8, which was validated only for heroin users, was translated into Spanish by Del Pozo [29] and German by Demmel [unavailable]. Despite the existence of a cross-cultural adaptation of the instrument, only the English-language version was used in other countries. Therefore, the present study's objective was to conduct a cross-cultural adaptation and translation of the DTCQ-8 for other drugs except alcohol and to verify its face validity, content and reliability in the pre-test stage, which will support the clinical process of validation in the Brazilian context.

The adapted DTCQ-8 version for other drugs may help Brazilian researchers in choosing their research methods and, ultimately, assist in the identification, evaluation, and monitoring of, and intervention in, high-risk situations for substance users. The outcomes achieved by health professionals will benefit from research tools that are useful for clinical practice.

\section{Methods \\ Participant recruitment and assessment}

The sample was consecutive, intentional and nonprobabilistic, with the following inclusion criteria: use of other drugs (other than alcohol), age 18-65 years, and undergoing treatment at CAPSad for at least a month. Exclusion criteria were cognitive limitations or medical and/or psychological states of health.

\section{Self-efficacy score}

The DTCQ-8 total score was calculated by averaging each user's scores for the eight items, and the selfefficacy level classification for each participant was based on the individual DTCQ-8 total score. Users were classified as having low self-efficacy if their individual DTCQ8 total score was below $20 \%$, moderate self-efficacy if the score was $20-80 \%$, and high self-efficacy if the score was above $80 \%$.

\section{Cross-cultural adaptation of the DTCQ-8 drug version for use in Brazil}

This was a methodological study of a cross-cultural adaptation of the DTCQ-8 for use in the Brazilian context. The objective was to achieve equivalence between the original version (developed in Canada) and the adapted version (for Brazil); it was essential for all items in the Brazilian version to maintain the validity of the instrument on a conceptual level [30,31]. The process was performed in accordance with the five steps described by Beaton et al. (2007) [30], which in turn were derived from work by Guillemin et al. (1993) [32]. Beaton and collleagues' procedure, described below, provides an important model for cross-cultural adaptation of healthstatus self-report questionnaires.

Step 1: Initial translation (T1 and T2): the DTCQ-8 version for other drugs was translated from English to Portuguese independently by two professionals fluent in English. One was in the health profession and aware of the research objectives; the other had different healthcare training and was unaware of the research objectives. These were called the $\mathrm{T} 1$ and $\mathrm{T} 2$ translations.

Step 2: Synthesis of translations: four authors (SVC, ISF, MDCL and VPR) integrated the translations (T1 and T2) and developed a single instrument called "synthesis T1/T2."

Step 3: Back-translation $\left(\mathrm{B}^{1} \mathrm{~T} 1 / \mathrm{T} 2\right.$ and $\left.\mathrm{B}^{2} \mathrm{~T} 1 / \mathrm{T} 2\right)$ : the synthesized instrument (T1/T2) was back-translated from Portuguese to English by two independent translators (not health professionals), who were double-blinded to the original version of the DTCQ-8 
for translation purposes and to the concepts explored in the survey. Both were Brazilians and native Portuguese speakers who were proficient in English. They produced two versions of the back-translation $\left(\mathrm{B}^{1} \mathrm{~T} 1 / \mathrm{T} 2\right.$ and $\mathrm{B}^{2} \mathrm{~T} 1 /$ T2), which were compared with the original DTCQ-8. Dr. Nigel, an author of the original instrument and the DTCQ used in this research, approved the entire process of cross-cultural adaptation using best practices from another study $[33,34]$ to assess the various aspects of cross-cultural validity.

Step 4: Committee of experts [35]: this committee, consisting of nine experts, was created to compare all the DTCQ-8 versions developed in the previous steps with the original DTCQ-8 questionnaire and produce a "pre-final" version of the DTCQ-8 in Brazilian Portuguese. This version was examined by the nine experts, who analyzed the synthesized version of the DTCQ-8; "T1/T2" was analyzed for face validity and content. Changes were made to the DTCQ- 8 according to the suggestions of this committee. These changes resulted in a pre-final Portuguese version of the DTCQ-8. The versions, including the pre-final version in Portuguese and the back-translation, were returned to the experts and to the author of the original scale (Dr. Nigel) in a manner similar to that described in Table 2. All approved the pre-final version, which was the instrument used in step 5 (pre-test).

Step 5: The pre-final version test (pre-test): the purpose of this step was to ensure that the adapted version retained content adequacy, writing clarity and usefulness in comparison to the original instrument, which was verified through research on its face validity and content for the target population. Although the instrument is self-administered, the researcher administered the pre-final version of the DTCQ- 8 by reading it individually to the pre-final sample of 40 adult drug users. The researcher also utilized a form to record the users' socio-demographics, clinical health and treatment status. In addition, the researchers used a specific instrument for semantic evaluation to record the understanding of each item and the meaning of the response provided by the target population [36]; this instrument evaluated the content's validity for the target population.

Step 5 was administered in a room that reflected the dynamics of CAPSad. In this setting, the adapted DTCQ-8 version (Table 2) was ready for statistical evaluation of its psychometric properties, namely, reliability, face validity and content validity. The authors, who have conducted a clinical validation in the Brazilian context and are currently writing articles about the process, administered the adapted DTCQ- 8 version of other drugs to a new sample-the final sample-and verified two psychometric properties: reliability (Cronbach's alpha) and construct validity (contrasted groups and factor analysis).

\section{Analysis \\ Descriptive statistics}

The descriptive statistics were obtained using absolute frequencies and percentages for three categorical variables and measures: average, standard deviation and median for numerical variables. The program used for typing and statistical calculations was the Statistical Package for Social Sciences (SPSS) version 21. In step 4, the expert committee obtained the satisfactory answers' frequency on each of the items evaluated, and from the results of each item, the scores were averaged to provide blocks. To check the reliability of the adapted DTCQ-8 version for other drugs, the relative internal consistency measure, Cronbach's alpha, was obtained for the prefinal sample. The data were double-entered by doubleblinded typists.

\section{Face validity of the DTCQ-8 as assessed by experts and by the target population of the pre-final sample}

The face validity of the adapted DTCQ- 8 was obtained through steps 4 and 5 . We asked the users and experts who participated in this study the following question: "To Sir/Madam, does the instrument clearly measure (appear to measure) the trust a drug user has in his or her confidence to resist the urge to use drugs in highrisk situations?" All said yes.

\section{Validity of DTCQ-8 content by experts and by the target population of the pre-final sample}

Content validity was determined by experts through semantic, experiential, and conceptual evaluation, and the concordance index $(\mathrm{CI})$ was calculated. A value greater than or equal to 0.80 is considered a parameter agreement among experts in this research [34]. Content validity by the target population was conducted by applying the semantic evaluation tool used in [36].

\section{Reliability of DTCQ-8 from data collected with the pre-final sample}

The instrument's internal consistency and reliability were verified by Cronbach's alpha; values greater than 0.70 were considered acceptable [37-41]. The Cronbach's alpha was calculated using a total of eight items; the exclusion of each item was used to identify the clinical behavior of the data from these changes to identify possible weaknesses in the instrument's internal consistency. In addition, we calculated the Spearman correlation coefficient to verify each item's influence on the internal consistency of the total instrument. 


\section{Results}

\section{Participant demographics}

The total sample $(n=40)$ comprised 20 Brazilian men and 20 women. The average age at the time of the study was $44.5 \pm 9.32$ years old. The substances used were crack and tobacco; these were responsible for their substance abuse problems and what motivated their treatment at the Psychosocial Care Center for Alcohol and Other Drugs (CAPSad). The participants' characteristics are shown in Table 1.

The age at first drug use among the crack users group was as follows: $15 \%$ began under 11 years old, $35 \%$ between 12 and 14 years old, $35 \%$ between 15 and 17 and
$15 \%$ between 18 and 65 . The average age at first drug use was 13.85 years old, and that of first crack use was 28.50 years old (SD: 7.30 years). Of the total group, $70 \%$ began their consumption of psychoactive substances with alcohol, $20 \%$ with marijuana and $10 \%$ with tobacco. The drug with the second most common use was marijuana (45\%), followed by tobacco (30\%). Crack was the most popular drug with the third (43.7\%), the fourth (63.6\%), or fifth (33.3\%) most prevalent contacts. Aspirated cocaine was also used during the second (5\%), fourth $(18.2 \%)$ and fifth $(66.7 \%)$ contacts. Thus, all users began their consumption of psychoactive substances by using crack or snorting cocaine. In addition,

Table 1 Socio-demographic characteristics of the 40 drug users in the pre-final sample

\begin{tabular}{|c|c|c|c|c|c|c|c|}
\hline \multirow[t]{3}{*}{ Variable } & \multicolumn{4}{|c|}{ Group } & \multirow{2}{*}{\multicolumn{2}{|c|}{ Total group }} & \multirow[t]{3}{*}{$p$ value } \\
\hline & \multicolumn{2}{|c|}{ Crack } & \multicolumn{2}{|c|}{ Tobacco } & & & \\
\hline & $\mathrm{N}$ & $\%$ & $\mathrm{~N}$ & $\%$ & $\mathrm{~N}$ & $\%$ & \\
\hline TOTAL & 20 & 100 & 20 & 100 & 40 & 100 & \\
\hline Age: Average and SD (years) & \multicolumn{2}{|c|}{$38.35 \pm 6.38$} & \multicolumn{2}{|c|}{$50.50 \pm 7.26$} & \multicolumn{2}{|c|}{$44.43 \pm 9.13$} & $\mathrm{p}^{(1)}<0.001^{*}$ \\
\hline \multicolumn{8}{|l|}{ Age group } \\
\hline Up to 39 years old & 12 & 60 & 2 & 10 & 14 & 35 & \multirow[t]{3}{*}{$\mathrm{p}^{(2)}<0.001^{*}$} \\
\hline $40-49$ & 8 & 40 & 6 & 30 & 14 & 35 & \\
\hline $50-65$ & - & - & 12 & 60 & 12 & 30 & \\
\hline \multicolumn{8}{|l|}{ Gender } \\
\hline Male & 19 & 95 & 1 & 5 & 20 & 50 & \multirow[t]{2}{*}{$\mathrm{p}^{(2)}<0.001^{*}$} \\
\hline Female & 1 & 5 & 19 & 95 & 20 & 50 & \\
\hline \multicolumn{8}{|l|}{ Color } \\
\hline White & 3 & 15 & 6 & 30 & 9 & 22.5 & \multirow[t]{3}{*}{$\mathrm{p}^{(3)}<0.323^{*}$} \\
\hline Black & 3 & 15 & 5 & 25 & 8 & 20 & \\
\hline Brown & 14 & 70 & 9 & 45 & 23 & 57.5 & \\
\hline \multicolumn{8}{|l|}{ Marital Status } \\
\hline Single & 11 & 55 & 11 & 55 & 22 & 55 & \multirow[t]{2}{*}{$p^{(1)}=0.001$} \\
\hline Married/Stable Union & 9 & 45 & 9 & 45 & 18 & 45 & \\
\hline \multicolumn{8}{|l|}{ Schooling } \\
\hline Illiterate & 2 & 10 & - & - & 2 & 5 & \multirow[t]{4}{*}{$p^{(3)}=0.021^{*}$} \\
\hline Up to 4 years & 10 & 50 & 4 & 20 & 14 & 35 & \\
\hline $5-8$ years & 5 & 25 & 5 & 25 & 10 & 25 & \\
\hline 9 years or more & 3 & 15 & 11 & 55 & 14 & 14 & \\
\hline \multicolumn{8}{|l|}{ Occupation } \\
\hline Unemployed & 6 & 30 & 7 & 35 & 13 & 32.5 & \multirow[t]{3}{*}{$p^{(2)}=0.811$} \\
\hline Officially registered & 5 & 25 & 6 & 30 & 11 & 27.5 & \\
\hline Informal work & 9 & 45 & 7 & 35 & 16 & 40 & \\
\hline \multicolumn{8}{|l|}{ Income } \\
\hline No income & 3 & 15 & 3 & 15 & 6 & 15 & \multirow[t]{4}{*}{$\mathrm{p}^{(3)}=0.772$} \\
\hline Less than Brazil's minimum wage & 8 & 40 & 6 & 30 & 14 & 35 & \\
\hline Minimum wage of Brazil & 4 & 20 & 7 & 35 & 11 & 27.5 & \\
\hline More than Brazil's minimum wage & 5 & 25 & 4 & 20 & 9 & 22.5 & \\
\hline
\end{tabular}

Source: Original compilation. ${ }^{*}$ ): Significant difference to the level of $5.0 \%$. (1): Student's $t$ test. (2): Chi-square Test of Pearson. (3): Fisher's exact test 
$45 \%$ reported they had been imprisoned in public jails, $55.55 \%$ practiced urban violence, and $44.44 \%$ engaged in domestic violence.

In the group of tobacco users, $20 \%$ began at 11 years old, $60 \%$ began between 12 and 13, $5 \%$ between 14 and 17 and $15 \%$ between 18 and 65 . The average age of first use was 13.95 years old (SD: 3.99 years). Of these, $95 \%$ started their consumption of psychoactive substances with tobacco and $5 \%$ with alcohol. All 20 smokers used only these two substances. No tobacco users had been arrested or had issues with the police.

Of the crack users, $85 \%$ had attended other treatment programs for their problem with this substance, $15.0 \%$ were in their first treatment, $23.5 \%$ had attended one or two treatments, $41.2 \%$ had attended three or four treatments, and $35.3 \%$ had attended more than 5 treatment programs. In addition, $41.2 \%$ abandoned the treatment due to a crack use relapse, and $58.8 \%$ abandoned the treatment because they considered it unnecessary. These individuals believed they were well or that the treatment was not providing improvements. None of the respondents were discharged from therapy.

Of the tobacco users, $40 \%$ had participated in other treatments for smoking, $60 \%$ were in their first treatment, $75 \%$ had participated in one or two treatments, and $25 \%$ had participated in three or four treatments. Of the total users, $75 \%$ abandoned the treatment because they did not see results and did not want to stay in treatment or quit smoking.

\section{Assessment of face and content validity by the committee of experts}

All of the experts reported that the adapted DTCQ-8 version for other drugs reliably measures drug users' confidence to resist the urge to consume these substances in high-risk situations. The assessment of the experts regarding the equivalence is shown in Table 2.

The concordance index for idiomatic equivalence of the A1 item was 0.778 due to a specialist's modification suggestion that was not accepted (A1 item: "Listed below are situations in which some people experience problems with drug use").

The evaluation by this study's specialists led to modifications of the A1, 1, 4, 5, 6 and 7 items, which were adjusted in accordance with the instructions received (Table 3); this resulted in the pre-final Portuguese version of the DTCQ- 8 for additional drugs (Table 4).

The evaluation based on clarity of the language (0.972), practical relevance (0.958) and theoretical relevance (0.958) showed average satisfactory scores (Table 5).

\section{Face and content validity (semantic evaluation) for the target population}

All users reported that the adapted DTCQ-8 version for other drugs measured their confidence to resist the urge to use drugs in high-risk situations. All users understood that item 2 was referring to not being able to sleep. Most participants asked the question: "Do I have confidence to say that I will not use?" In Section 4, most participants asked: "What if I wanted to test myself?"

On items 7 and 8, some users said they did not accept invitations for drug use and did not celebrate with friends, requiring the researcher's intervention regarding the scale filling instructions. DTCQ-8 assumes the mental anticipation of high-risk situations, i.e., the user needs to imagine the situation at hand.

Table 2 Evaluation of the equivalences of the pre-final version of DTCQ-8 for other drugs

Semantic equivalence

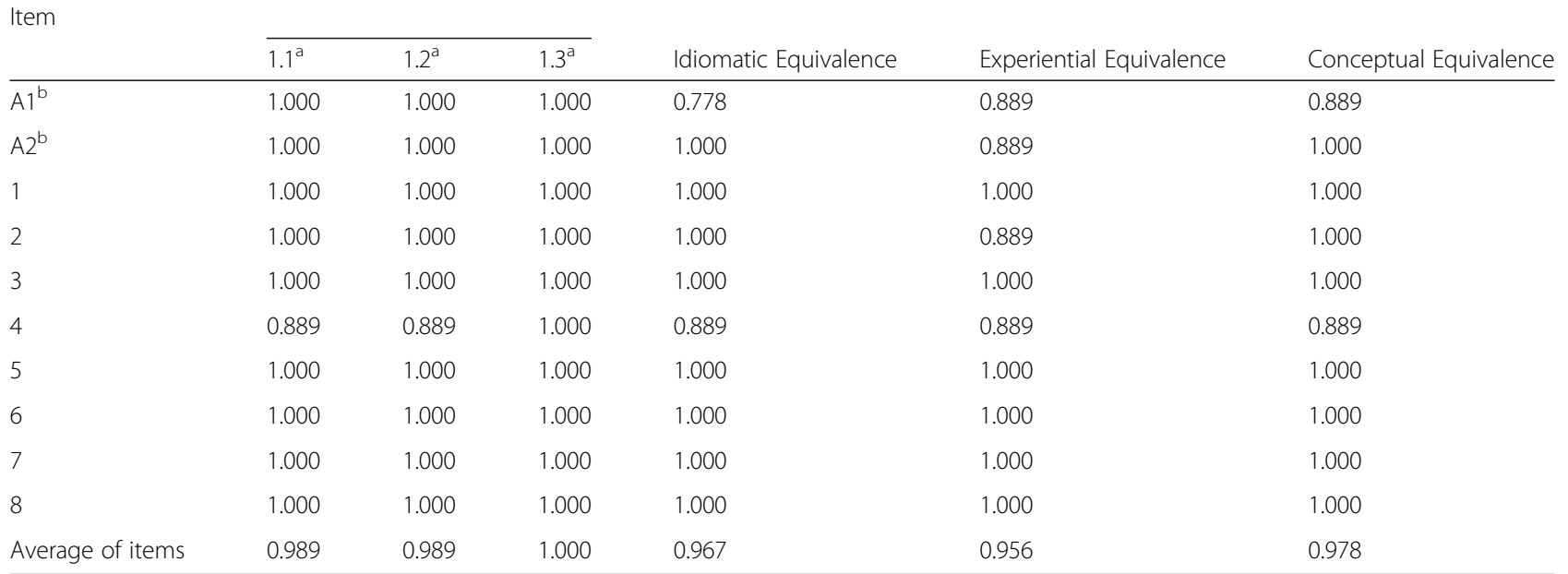

${ }^{\mathrm{a}} 1.1$ correct writing, 1.2 equivalent significance, 1.3 grammatically correct

${ }^{b}$ Explanatory paragraphs on the scale and filled 
Table 3 Modified items from the suggestions of the Committee of experts

\begin{tabular}{|c|c|c|}
\hline Original DTCQ-8 & Itens da Versão "Síntese T12" DTCQ-8 & Itens da Versão pré-final DTCQ-8 \\
\hline $\begin{array}{l}\text { A1. Imagine yourself as if you are right now } \\
\text { in each of these situations. }\end{array}$ & $\begin{array}{l}\text { A1. Imagine-se você agora mesmo em cada } \\
\text { uma dessas situações. }\end{array}$ & $\begin{array}{l}\text { A1. Imagine-se agora em cada uma dessas } \\
\text { situações. }\end{array}$ \\
\hline $\begin{array}{l}\text { 1. If I were angry at the way things had } \\
\text { turned out. }\end{array}$ & $\begin{array}{l}\text { 1. Se eu estivesse com raiva pelo rumo que as } \\
\text { coisas tomaram. }\end{array}$ & 1. Se, por algum motivo, eu estivesse com raiva. \\
\hline $\begin{array}{l}\text { 4. If I wanted to find out whether I could use } \\
\text { hooked. }\end{array}$ & $\begin{array}{l}\text { 4. Se eu quisesse me testar se consigo usar } \\
\text { às vezes sem me viciar. }\end{array}$ & $\begin{array}{l}\text { 4. Se eu quisesse testar se consigo usar } \\
\text { às vezes, sem me tornar dependente. }\end{array}$ \\
\hline $\begin{array}{l}\text { 5. If I unexpectedly found some } \\
\text { or happened to see something that } \\
\text { reminded me of }\end{array}$ & $\begin{array}{l}\text { 5. Se eu por acaso encontrasse alguma droga } \\
\text { ou visse alguma coisa que me } \\
\text { lembrasse a droga }\end{array}$ & $\begin{array}{l}\text { 5. Se eu, por acaso, encontrasse alguma droga } \\
\text { ou visse alguma coisa que me } \\
\text { lembrasse o ato de usar }\end{array}$ \\
\hline $\begin{array}{l}\text { 6. If other people treated me unfairly or } \\
\text { interfered with my plans. }\end{array}$ & $\begin{array}{l}\text { 6. Se outra pessoa me tratasse mal ou } \\
\text { atrapalhasse meus planos. }\end{array}$ & $\begin{array}{l}\text { 6. Se alguém me tratasse injustamente ou } \\
\text { atrapalhasse meus planos. }\end{array}$ \\
\hline $\begin{array}{l}\text { 7. If I were out with friends and they kept } \\
\text { suggesting we go somewhere and use }\end{array}$ & $\begin{array}{l}\text { 7. Se eu estivesse com amigos e eles insistissem } \\
\text { para sairmos para usar }\end{array}$ & $\begin{array}{l}\text { 7. Se eu estivesse com amigos e eles insistissem } \\
\text { para irmos a algum lugar para usar }\end{array}$ \\
\hline
\end{tabular}

Most users needed clarification of items 4, 7 and 8 . They claimed they did not test themselves and did not accept invitations because they knew they would not resist the urge to use drugs in these situations.

\section{DTCQ-8 version for other drugs reliability}

The results of the DTCQ-8 version of the reliability for other drugs were obtained from Cronbach's alpha; these are described in Table 6.

Given the above observations, the pre-final Portuguese version of the DTCQ-8 for other drugs, its backtranslation and the comparison with the original showed a satisfactory translation of the instrument under consideration because the differences were derived from the cross-cultural adaptation to Brazil (Tables 3 and 4).

\section{Self-efficacy scores using the adapted DTCQ-8 version for other drugs}

The average total scores of the self-efficacy to resist the urge to use drugs was 67.50 for crack users and 52.50 for tobacco users. Thus, $5 \%$ of users were classified as having low self-efficacy, $67.5 \%$ as moderate self-efficacy and $27.5 \%$ as high self-efficacy (Table 7).

We found that item 4 ("If I wanted to test if I can use sometimes without becoming dependent"), which corresponds to "Domain: Personal control test," had a lower average $(35.50+40.46$ - DP) of self-efficacy to resist the urge to use drugs in this particular situation. In contrast, the highest average $(78.50 \pm 32.78$-SD) of selfefficacy was in response to item 3 ("If I remember something good that happened"), which corresponds to "Domain: pleasant emotions," demonstrating that item 3

Table 4 Comparison of the original version of the DTCQ-8 and cross-cultural adaptation

\begin{tabular}{|c|c|c|}
\hline Original DTCQ-8 & Versão pré-final em português DTCQ-8 & Retrotradução DTCQ-8 \\
\hline $\begin{array}{l}\text { 1. If I were angry at the way things had } \\
\text { turned out. }\end{array}$ & 1. Se, por algum motivo, eu estivesse com raiva. & 1. If, for some reason, I was angry. \\
\hline 2. If I had trouble sleeping. & 2. Se eu tivesse problemas para dormir. & 2. If I had trouble sleeping. \\
\hline $\begin{array}{l}\text { 3. If I remembered something good that had } \\
\text { happened. }\end{array}$ & $\begin{array}{l}\text { 3. Se eu lembrasse de alguma coisa boa que tivesse } \\
\text { acontecido. }\end{array}$ & $\begin{array}{l}\text { 3. If I remembered something good that had } \\
\text { happened. }\end{array}$ \\
\hline $\begin{array}{l}\text { 4. If I wanted to find out whether I could use } \\
\text { hooked. }\end{array}$ & $\begin{array}{l}\text { 4. Se eu quisesse testar se consigo usar } \\
\text { às vezes, sem me tornar dependente. }\end{array}$ & $\begin{array}{l}\text { 4. If I wanted to test if I could use } \\
\text { sometimes, without becoming dependent. }\end{array}$ \\
\hline $\begin{array}{l}\text { 5. If I unexpectedly found some } \\
\text { or happened to see something that reminded } \\
\text { me of }\end{array}$ & $\begin{array}{l}\text { 5. Se eu, por acaso, encontrasse alguma droga } \\
\text { lembrasse o ato de usar }\end{array}$ & $\begin{array}{l}\text { 5. If I, by chance, found some drug } \\
\text { or saw something that reminded me of the } \\
\text { act of using }\end{array}$ \\
\hline $\begin{array}{l}\text { 6. If other people treated me unfairly or } \\
\text { interfered with my plans. }\end{array}$ & $\begin{array}{l}\text { 6. Se alguém me tratasse injustamente ou } \\
\text { atrapalhasse meus planos. }\end{array}$ & $\begin{array}{l}\text { 6. If somebody treated me unfairly or } \\
\text { interfered with my plans. }\end{array}$ \\
\hline $\begin{array}{l}\text { 7. If I were out with friends and they kept } \\
\text { suggesting we go somewhere and use }\end{array}$ & $\begin{array}{l}\text { 7. Se eu estivesse com amigos e eles insistissem } \\
\text { para irmos a algum lugar para usar }\end{array}$ & $\begin{array}{l}\text { 7. If I was with some friends and they insisted } \\
\text { to go some place to use }\end{array}$ \\
\hline 8. If I wanted to celebrate with a friend. & 8. Se eu quisesse comemorar com um amigo. & 8. If I wanted to celebrate with a friend. \\
\hline
\end{tabular}


Table 5 Content validity of the pre-final version of the DTCQ-8 for other drugs

\begin{tabular}{lccc}
\hline Item of DTCQ-8 & $\begin{array}{c}\text { Clarity of } \\
\text { language }\end{array}$ & $\begin{array}{c}\text { Practical } \\
\text { relevance }\end{array}$ & $\begin{array}{c}\text { Theoretical } \\
\text { relevance }\end{array}$ \\
\hline 1 & 1.000 & 0.889 & 0.889 \\
2 & 0.778 & 0.889 & 0.889 \\
3 & 1.000 & 0.889 & 0.889 \\
4 & 1.000 & 1.000 & 1.000 \\
5 & 1.000 & 1.000 & 1.000 \\
6 & 1.000 & 1.000 & 1.000 \\
7 & 1.000 & 1.000 & 1.000 \\
8 & 1.000 & 1.000 & 1.000 \\
Average of the items & 0.972 & 0.958 & 0.958 \\
\hline
\end{tabular}

does not represent a high risk for other drug users participating in the study.

The results in Table 8 demonstrate that it is possible to verify that the majority in each group had mild selfefficacy, with percentages ranging from $70 \%$ for crack users to $65 \%$ for tobacco users, followed by high selfefficacy, with percentages between $30 \%$ and $25 \%$, respectively. However, there was no significant difference $(p>0.05)$ between groups regarding the participants' self-efficacy level classification.

\section{Discussion}

\section{Participants' demographics}

The sociodemographic characteristics of this study were similar to those in other studies of cross-cultural adaptation of instruments for drug users [42, 43]. However, some methodological studies of cross-cultural adaptation and translation do not report the sociodemographic of their targeted population and focus solely on the gender [44] and other aspects of the study [45]. These studies demonstrate that the emphasis on methodological studies is the same as that of the method used in crosscultural adaptations [46-48], which, in the present study, was the guideline by Beaton et al. (2007) [30]. Differences were identified concerning the sociodemographic characteristics among the targeted population of this study and the original DTCQ-8 article, education, type of consumed psychoactive substances and employment status.

The results of the current study results indicate that the average age of first cigarette consumption was lower than previously found in Brazilian research studies [6]. In addition, the beginning of crack use [49] was higher than in other Brazilian studies. There are similar results regarding the urban and domestic violence among crack users [6]. Urban violence is also associated with illicit drug trafficking and as a way of obtaining the substance [50].

\section{Assessment of face and content validity by the committee of experts}

The translation process and cultural adaptation of measuring instruments take into account the target population's context or culture to preserve the meaning of the construct assessed [51, 52]. An committee comprising professionals from various backgrounds contributed to the analysis of the instrument from different perceptions and perspectives $[53,54]$. The changes made to the adapted instrument are considered reasonable and necessary because they facilitate understanding by the targeted population [55-58].

This process has shown that the instrument is easy to administer and can be completed in a satisfactory amount of time.

\section{Face and content validity for the targeted population}

The face validity was similar to that reported in another Brazilian article [59]. There are studies that have the same targeted population and discuss the instrument regarding the aspects of face validity and content [36]. However, our article used the content validity method, as have other Brazilian studies [37-39].

Table 6 Cronbach's alpha values and Spearman's correlation coefficient of the DTCQ-8 for other drugs

\begin{tabular}{lcc}
\hline DTCQ-8 for other drugs & Total item correlation ${ }^{\text {a }}$ r & Alpha if item deleted \\
\hline 1. If, for some reason, I was angry & 0.780 & 0.837 \\
2. If I had trouble sleeping & 0.871 & 0.675 \\
3. If I remember anything good that happened & 0.883 & 0.863 \\
4. If I wanted to test whether I can use __ sometimes without becoming dependent on it & 0.551 & 0.890 \\
5. If I find any drugs of __ or see something that I could remember the act of using _ & 0.665 & 0.869 \\
6. If someone treats me unjustly or gets in the way of my plans & 0.877 & 0.868 \\
7. If I was with friends and they insisted on going somewhere for use of __ & 0.876 \\
8. If I wanted to celebrate with a friend
\end{tabular}

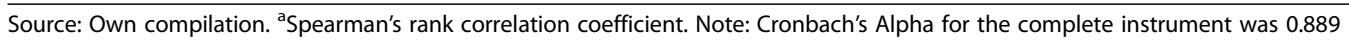


Table 7 Self-efficacy scores according to the group that responded to the DTCQ-8

\begin{tabular}{llll}
\hline Items of DTCQ-8 & $\begin{array}{l}\text { Crack } \\
\text { Median (IQR) }\end{array}$ & $\begin{array}{l}\text { Tobacco } \\
\text { Median (IQR) }\end{array}$ & $p$ value \\
\hline 1 & $60(75)$ & $40(75)$ & $p^{(1)}=0.366$ \\
2 & $100(15)$ & $90(60)$ & $p^{(1)}=0.047^{*}$ \\
3 & $100(20)$ & $90(60)$ & $p^{(1)}=0.201$ \\
4 & $20(90)$ & $20(85)$ & $p^{(1)}=0.987$ \\
5 & $80(80)$ & $40(90)$ & $p^{(1)}=0.134$ \\
6 & $80(80)$ & $40(100)$ & $p^{(1)}=0.380$ \\
7 & $70(80)$ & $70(80)$ & $p^{(1)}=0.911$ \\
8 & $90(80)$ & $100(90)$ & $p^{(1)}=0.956$ \\
DTCQ-8 complete & $67.50(46.87)$ & $52.50(58.13)$ & $p^{(1)}=0.272$ \\
\hline
\end{tabular}

Source: Own compilation. $\left(^{*}\right)$ : Significant difference to the level of $5.0 \%$. (1): Mann-Whitney test

\section{Confirmability of the adapted DTCQ-8 version for other drugs}

Cronbach's alpha yielded values similar to those of the original scale [26, 28], showing reliability of the instrument as applied to the Brazilian population in this study [37-39].

\section{Self-efficacy scores DTCQ-8 version for other drugs}

The personal control test was identified as a high-risk and low-efficacy situation for resisting the desire to consume drugs, which is a result similar to that of other studies $[60,61]$. Thus, when the users understand their behavior pattern and problems associated with the consumption of psychoactive substances, their self-efficacy increases and they become able to resist the urge of consuming drugs. The domain "pleasant emotions" was not considered a high-risk situation for consuming drugs because the users attained higher self-efficacy levels to resist the desire of using these drugs [62].

Therefore, stimulating the seeking of healthy habits that provide new forms of pleasure is an important strategy for behavioral change [63, 64].

Drug users' behavioral dynamics on their confidence to resist the urge to consume these substances in highrisk situations was similar to those of other studies $[65,66]$.
The classification of users of other drugs in this study who have moderate self-efficacy was similar to that in other studies [67]; it is believed that this classification can be related to the behavioral dynamics of users seeking treatment [68].

\section{Conclusion}

The adapted DTCQ-8 version for other drugs was translated, culturally adapted and validated for the pre-final sample; this is a useful tool for clinicians and researchers in the evaluation of drug user self-efficacy to resist the urge to consume these substances in high risk situations. Furthermore, this study contributes to the planning of interventions, the monitoring of changes in users and the evaluation of treatment effectiveness.

The present research is limited by presenting the reliability and validity evaluation as an adapted DTCQ-8 version for other drugs in which the psychometric properties have only been tested for pre-final sample.

This limitation will be rectified in our next article regarding the clinical validation of the adapted DTCQ-8 version for other drugs for use in Brazil. The clinic validation was made with a new sample of drug users in CAPSad. The content's validity was evaluated through contrasted groups and factor analysis, and the instrument's internal consistency was verified by Cronbach's alpha.

\section{Ethics approval and consent to participate}

The study was approved by the Ethics Committee in Research with Human Beings-UFPE under CAAE 31677114.0.0000.5208. We received permission to use this instrument from the Centre for Addiction \& Mental Health (CAHM) and obtained written informed consent from all participants (drug users and experts).

\section{Consent to publish}

All authors read and approved the final version of the manuscript.

All authors have consented to publication of this manuscript.

All study participants signed free and informed consent. They also agreed to publish the data.

Table 8 Classification of the self-efficacy according to the group that answered the DTCQ-8

\begin{tabular}{|c|c|c|c|c|c|c|c|}
\hline \multirow{3}{*}{$\begin{array}{l}\text { Classification of self-efficacy according to the average } \\
\text { score of the DTCQ-8 }\end{array}$} & \multicolumn{4}{|c|}{ Group } & \multirow{2}{*}{\multicolumn{2}{|c|}{$\begin{array}{l}\text { Group } \\
\text { Total }\end{array}$}} & \multirow[t]{3}{*}{$p$ value } \\
\hline & \multicolumn{2}{|c|}{ Crack } & \multicolumn{2}{|c|}{ Tobacco } & & & \\
\hline & $\overline{\mathrm{N}}$ & $\%$ & $\overline{\mathrm{N}}$ & $\%$ & $\overline{\mathrm{N}}$ & $\%$ & \\
\hline Low (Average of the instrument $<20 \%$ ) & - & - & 2 & 10 & 2 & 5 & $p^{(1)}=0.565$ \\
\hline Moderate (Average of the instrument from $20 \%$ to $80 \%$ ) & 14 & 70 & 13 & 65 & 27 & 67.5 & \\
\hline High (Average of the instrument $>80 \%$ ) & 6 & 30 & 5 & 25 & 11 & 27.5 & \\
\hline TOTAL & 20 & 100 & 20 & 100 & 80 & 100 & \\
\hline
\end{tabular}




\section{Availability of data and materials}

If you want access to complete data on the doctoral thesis, contact the corresponding author by email selumares@gmail.com.

\section{Abbreviations}

DTCQ-8: Drug-taking confidence questionnaire; CAPSad: Day-care center for alcohol and other drugs.

\section{Competing interests}

The authors declare that they have no competing of interests.

\section{Authors' contributions}

All of the authors meet at least one of the following criteria (recommended by the ICMJE: http://www.icmje.org/ethical_1author.html) and have agreed on the final version: SCV, EBS, ISF and MDCL performed substantial contributions to the study conception and design, acquisition of data, or analysis and interpretation of data; NET and VPR critically revised the manuscript for important intellectual content. All authors read and approved the final manuscript.

\section{Authors' information}

SCV, Nurse, Doctorate in Neuropsychiatry and Behavioral Sciences, Professor of Graduate in Nursing Federal University of Paraíba-UFPB, João Pessoa, Paraíba, Brazil.selumares@yahoo.com.br. EBS, Psychiatrist, Doctorate in Mental Health, Professor of Postgraduate Program in Neuropsychiatry and Behavioral Sciences, Federal University of Pernambuco-UFPE, Recife, Pernambuco, Brazil. evertonbs@yahoo.com. ISF, Nurse, Doctorate in Social Work, Professor of Postgraduate Program in Nursing, UFPE, Recife, Pernambuco, Brazil. isfrazao@ gmail.com. NET, Epidemiologist, Philosophical Doctorate in Psychology, Assistant Professor, Dalla Lana School of Public Health, University of Toronto and Independent Scientist, Center for Addiction and Mental Health, Toronto. nigel.turner@camh.ca. VPR, Nurse, Doctorate in Neuropsychiatry and Behavioral Sciences, Professor of Postgraduate Program in Nursing, UFPE, Recife, Pernambuco, Brazil.vpinheiroramos@uol.com.br. MDCL, Psychiatrist, Doctorate in Psychiatry, Professor of Postgraduate Program in Neuropsychiatry and Behavioral Sciences, UFPE, Recife, Pernambuco, Brazil.

murilocostalima@ig.com.br

\section{Acknowledgements}

We acknowledge the participants of the study, the service professionals, and the contributions of Prof. Dr. Ana Karina Bezerra Pinheiro, Prof Dr. Lorena Barbosa Ximenes, and Prof. Dr. Edmilson Mazza. In addition, we acknowledge the Center for Addiction and Mental Health for authorization of the use of the DTCQ-8 original.

Adapted from the doctoral thesis "Drug-Taking Confidence Questionnaire Validation for use in Brazil," presented at the Federal University of Pernambuco, Recife-PE, Brazil.

\section{Funding}

This research received no specific grant from any funding agency in the public, commercial, or not-for-profit sectors.

\section{Author details}

${ }^{1}$ Federal University of Paraíba-UFPB, João Pessoa, Brazil. ${ }^{2}$ Federal University of Pernambuco-UFPE, Recife, Brazil. ${ }^{3}$ University of Toronto and Independent Scientist, Center for Addiction and Mental Health, Toronto, Canada.

Received: 29 May 2015 Accepted: 4 May 2016

Published online: 18 May 2016

\section{References}

1. Oliveira EB, Kestenberg CCF, Silva AV. Mental health and teaching about drugs in nursing graduation: participatory methodologies. Esc Anna Nery Rev Enferm. 2007:11(4):722-7.

2. OPAS. Pan American Health Organization \& World Health Organization (Eds): Report on world health. Mental health: new understanding, new hope. Graphic Brazil: Brasília; 2001

3. Pratta EMM, Santos MA. The health-disease process and drug addiction: interfaces and evolution. Psicol: Teo e Pesq. 2009;25(2):203-11.
4. Raupp L, Adorno RCF. Crack usage circuits in the downtown area of the city of São Paulo (SP, Brazil). Ciência Saúde Coletiva. 2011;16(5):2613-22.

5. UNODC. United Nations Office on Drugs and Crime. World Drug Report. New York: United Nations Publication; 2014.

6. Laranjeira R (supervision) [et al.]. II National Alcohol and Drug Survey - 2012. São Paulo: National Institute of Science and Technology for Public Policy on Alcohol and Other Drugs- UNIFESP, 2014

7. Dias AC, Araújo MR, Dunn J, Sesso RC, De Castro V, Laranjeira R. Mortality rate among crack/cocaine-dependent patients: a 12-year prospective cohort study conducted in Brazil. J Subst Abuse Treat. 2011;41(3):273-8.

8. Ministry of Planning, Budget and Management Brazilian Institute of Geography and Statistics - IBGE, Directorate of Research Coordination Work and Income Rio de Janeiro 2014. National Health Survey 2013 Perceived health status, lifestyles and chronic diseases Brazil, Major regions and Federative Units. 2014

9. Costa LCS, Navas ALGP, Oliveira CCC, Ratto LRC, Carvalho KHP, Silva HR, Lopes C, Tieppo CA. Phonological memory evaluation and impulsiveness of drug users treated at a center of integrated mental health care. Rev CEFAC. 2012;14(3):438-47.

10. Almeida RMM, Flores ACS, Scheffer M. Suicidal ideation, problem solving, expression of anger and impulsivity in addicted to psychoactive substances. Psicologia: Reflexão \& Critica. 2013;26:1.

11. Peuker AC, Lopes FM, Menezes CB, Cunha SM, Bizarro L. Implicit Processing and Chemical Dependency: Theory, Assessment and Prospects. Psicologia: Teoria e Pesquisa. 2013;29(1):7-14.

12. Bandura A. Self-Efficacy: Toward unifying theory of behavior change. Psychol Rev. 1977:84(2):191-215.

13. Bandura A. A sociocognitive analysis of substance abuse: an agentic perspective. Psychol Sci. 1999;10(3):214-7.

14. Bandura A. Human agency in social cognitive theory. Amer Psychologist. 1989:44:1175-84.

15. Pajares F, Olaz F. Teoria social cognitiva e auto-eficácia: uma visão geral. In: Bandura A, Azzi RG, Polydoro S, editors. Teoria social cognitiva: conceitos básicos. Porto Alegre: Artmed; 2008. p. 97-114.

16. Wolff N, Hueninga J, Shi J, Frueh BC, Hoover DR, McHugo G. Implementation and effectiveness of integrated trauma and addiction treatment for incarcerated men. J Anxiety Disord. 2015:30:66-80.

17. LaChance H, Cioe PA, Tooley E, Colby SM, O'Farrell TJ, Kahler CW. Behavioral Couples Therapy for Smoking Cessation: A Pilot Randomized Clinical Trial. Psychol Addict Behav. 2015;29(3):643-52.

18. Guo SE, Wang AL, Shu BC. Self-efficacy in providing smoking-cessation services among psychiatric nurses in central and southern Taiwan: An exploratory study. Int J Ment Health Nurs. 2015;24(2):158-68.

19. Formigoni MLOS, Castel S. Rating scales of drug dependence: general aspects. Rev Psiquiatr Clín. 1999;26(1,n.esp):5-31.

20. Matos MTS, Bastos ENE, Matos EC, Vasconcelos SMM. The use of evaluation scales as therapeutic tools in patients seen at a service for drug rehabilitation in Fortaleza-CE. Rev RENE. 2006;7(2):9-16.

21. Mensinger JL, Lynch KG, TenHave TR, McKay JR. Mediators of telephonebased continuing care for alcohol and cocaine abuse. J Consult Clin Psychol. 2007;75(5):775-84

22. Lynch KG, Van Horn D, Drapkin M, Ivey M, Coviello D, McKay JR. Moderators of response to telephone continuing care for alcoholism. Am J Health Behav. 2010:34(6):788-800.

23. Sánchez-Hervás E, Del Pozo JML. Relapse in cocaine addiction: a review. Adicciones. 2012:24(3):269-80.

24. Billingham DD, Kelly PJ, Deane FP, Crowe TP, Buckingham MS, Craig FL. Clinically Significant Change to Establish Benchmarks in Residential Drug and Alcohol Treatment Services. Int J Ment Health Addiction. 2012;10:890-901.

25. Annis HM, Martin G. Inventory of drug-taking situations. Toronto: Addiction Research Foundation; 1985.

26. Sklar SM, Annis HM, Turner NE. Development and validation of the drug-taking confidence questionnaire: a measure of coping self-efficacy. Addict Behav. 1977;22(5):655-70.

27. Annis HM, Sklar SM, Turner NE. Drug-Taking Confidence Questionnaire (DTCQ): Users guide. Toronto: Addiction Research Foundation of Ontario; 1996.

28. Sklar SM, Turner NE. A brief measure for the assessment of coping selfefficacy among alcohol and other drug users. Addiction. 1999:94(5):723-9.

29. Del Pozo JML. Validación del DTCQ-H a la población Española. "cuestionario de confianza ante situaciones de riesgo de consumo de heroína". Madrid: Thesis Doctorado; 1997. 
30. Beaton DE, et. al. Recommendations for the corss-cultural adaptation of DASH \& QuickDASH outcome measures. [S.I.]: Institute for Work \& Health. 2007. Available at: https://www.researchgate.net/profile/Claire_Bombardier/ publication/265000941_Recommendations_for_the_Cross-Cultural_ Adaptation_of_the_DASH_QuickDASH_Outcome_Measures_Contributors_ to_this_Document/links/53fdd6140cf22f21c2f85143.pdf. Access on: Jan 2013.

31. Wild D, Grove A, Martin M, Eremenco S, McElroy S, Verjee-Lorenz A, Erikson P. ISPOR Task Force for Translation and Cultural Adaptation: Principles of good practice for the translation and cultural adaptation process for patient-Reported Outcomes (PRO) Measures: report of the ISPOR Task Force for translation and cultural adaptation. Value Health. 2005:8:94-104.

32. Guillemin F, Bombardier C, Beaton D. Cross-cultural adaptation of health-related quality of life measures: literature review and proposed guidelines. J Clin Epidemiol. 1993;46(12):1417-32.

33. Carvalho AB, Garcia JBS, Silva TKM, Ribeiro JVF. Traduction and cross-cultural adaptation of Pain Quality Assessment Scale (PQAS) to brazilian version. Rev Bras Anestesiolo. 2014;66(1):94-104.

34. Pasquali $L$ et al. Psychological instrumentation: principles and practices. Porto Alegre: Artmed; 2010

35. Fehring RJ. The Fehring model. In: Carrolol-Johnson RM, Paquete M, editors. Classification of nursing diagnoses: proceding ot the Tenth Conference of NorthAmerican Nursing Diagnosis Association. Philadelphia: JB Linppincott; 1994.

36. ITC International Test Commission. ITC Guidelines of adapting tests. Avalaible: https://www.intestcom.org/.

37. Oliveira MF. Cross-adaptation and validation of Maternal Postpartum Quality of Life Questionnaire: applied in Brazilian mothers. Ana Karina Bezerra Pinheiro: Professor. 2014. p. 177.

38. Symon A, Nagpal J, Mani Ecka-Bryła I, Nowakowska-Gła BA, Rashidian A, Khabiri R, Mendes I, Pinheiro AKB, Oliveira MF, Wu L. Cross-cultural adaptation and translation of a quality of life tool for new mothers: a methodological and experiential account from six countries. J Adv Nurs. 2012. 00(0), 000:000-0; doi:10.1111/j.1365-2648.2012.06098.x.

39. Fonseca VJ, Ximenes LB, Almeida PC. Cross-cultural adaptation of the Exercise Benefi ts/Barriers Scale (EBBS) for application in elderly Brazilians: preliminary version. Caderno de Saúde Pública. 2008;24(12):2852-60.

40. Cronbach $\sqcup$. Coefficient alpha and the internal structure of tests. Psychometrika. 1951;16(3):297-334.

41. Gliem JA, Gliem RR. Calculating, Interpreting, and Reporting Cronbach's Alpha Reliability Coefficient for Likert-Type Scales. 82-88. 2003. Presented at the Midwest Research-to-Practice Conference in Adult, Continuing, and Community Education, The Ohio State University, Columbus, OH, October 8-10, 2003

42. Awaisu A, Samsudin S, Amir NA, Omar CG, Hashim MI, Mohamad MHN, Shafie AA, Hassali MA. Measurement of nicotine withdrawal symptoms: linguistic validation of the Wisconsin Smoking Withdrawal Scale (WSWS) in Malay. BMC Med Res Methodol. 2010;10(46):1-7

43. Santos MP, Rocha MR, Araújo RB. The use of cognitive technique replacement by positive image in the management of craving for crack-cocaine-dependent patients. J Bras Psiquiatr. 2014;63(2):121-6.

44. Fernandes S, Ferigolo M, Benchaya MC, Pierozan PS, Moreira TC, Santos V, Mazoni CG, Barros HMT. Cannabis abuse and dependency: differences between men and women and readiness to behavior change among users seeking treatment. Rev Psiquiatr Rio Gd Sul. 2010;32(3):80-5.

45. Moreira IC, Bandeira M, Pollo TC, Oliveira MS. Cross-cultural adaptation to Brazil of Medication Adherence Rating Scale for psychiatric patients. J Bras Psiquiatr. 2014;63(4):273-80.

46. Geri T, Signori A, Gianola S, Rossettini G, Grenat G, Checchia G, Testa M. Cross-cultural adaptation and validation of the Neck Bournemouth Questionnaire in the Italian population. Qual Life Res. 2015;24:735-45.

47. Oyeyemi AL, Oyeyemi AY, Adegoke BO, Oyetoke FO, Aliyu HN, Aliyu SU, Rufai AA. The short international physical activity questionnaire: cross-cultural adaptation, validation and reliability of the Hausa language version in Nigeria. BMC Med Res Methodol. 2011;11:156,1-11.

48. Schuster C, Lussi A, Wirth B, Ettlin T. Two assessments to evaluate imagery ability: translation, test-retest reliability and concurrentvalidity of the German KVIQ and Imaprax. BMC Med Res Methodol. 2012;12:127,1-13.

49. Sapori LF, Sena LL, Silva BFA. Crack the market and urban violence in the city of Belo Horizonte. Dilemas. 2012;5(1):37-66.

50. Chaves TV, Sanchez ZM, Ribeiro LA, Nappo SA. Crack cocaine craving: behaviors and coping strategies among current and former users. Rev Saude Publica. 2011;45(6):1168-75.
51. Reichenheim ME, Moraes CL. Operationalizing the cross-cultural adaptation of epidemiological measurement instruments. Rev Saude Publica. 2007:41(4):665-73.

52. Hambleton RK. Issues, Designs and Technical Guidelines for Adapting Tests Into Multiple Languages and Cultures. In: Hambleton RK, Merenda PF, Spielberger CD, editors. Adapting Psychological and Educational Tests for Cross-Cultural Assessment. NJ: Lawrence Erlbaum; 2005.

53. Touma Z, Ghandour L, Sibai A, Puzantian H, Hamdan A, Hamdan O, Menassa J, Uthman I, Arayssi T. Cross-cultural adaptation and validation of Behçet's disease quality of life questionnaire. BMC Med Res Methodol. 2011;11(52):1-7.

54. Lane DA, Jajoo J, Taylor RS, Lip GYH, Jolly K, the Birmingham Rehabilitation Uptake Maximisation (BRUM) Steering Committee. Cross-cultural adaptation into Punjai of the English version of the Hospital Anxiety and Depression Scale. BMC Psychiatry. 2007;7(5):1-8.

55. Gudmundsson F. Guidelines for translating and adapting psychological instruments. Nordic Psychol. 2009;61(2):29-45.

56. Sousa VD, Rojjanasrirat W. Translation, adaptation and validation of instruments or scales for use in cross-cultural health care research: a clear and user-friendly guideline. J Eval Clin Pract. 2011;17:268-74.

57. Borsa JC, Damásio BF, Bandeira DR. Cross-cultural adaptation and validation of psychological instruments: some considerations. Paidéia. 2012;22(53):423-32.

58. Gjersing L, Caplehorn JRM, Clausen T. Cross-cultural adaptation of research instruments: language, setting, time and statistical considerations. BMC Med Res Methodol. 2010;10(13):1-10.

59. Freitas NO, Caltran MP, Dantas RAS, Rossi LA. Translation and cultural adaptation of the perceived stigmatization questionnaire for burn victims in Brazil. Rev Esc Enferm USP. 2014;48(1):25-33.

60. Krenek M, Maisto SA. Life events and treatment outcomes among individuals with substance use disorders: A narrative review. Clin Psychol Rev. 2013;33:470-83.

61. Courbasson CM, Rizea C, Weiskopf N. Emotional Eating among Individuals with Concurrent Eating and Substance Use Disorders. Int J Ment Health Addiction. 2008;6:378-88.

62. Senbanjo R, Wolff K, Marshall EJ, Strang J. Persistence of heroin use despite methadone treatment: Poor coping self-efficacy predicts continued heroin use. Drug Alcohol Rev. 2009;28:608-15.

63. Vasconcelos SC, Frazão IS, Ramos VP. Health Education therapy group contributions in the motivation to the psychoactive substances user's life. Enfermagem em Foco. 2012;3(3):123-6.

64. Hori AA, Nascimento AF. The Singular Therapeutic Project and mental health practices at Family Health Support Centers in Guarulhos in the state of São Paulo. Brazil Ciência e Saúde Coletiva. 2014;19(8):3561-71.

65. Berry SL, Crowe TP, Deane FP, Billingham M, Bhagerutty Y. Growth and Empowerment for Indigenous Australians in Substance Abuse Treatment. Int J Ment Health Addiction. 2012;10:970-83.

66. Pashaei T, Shojaeizadeh D, Foroushani AR, Ghazitabatabae M, Moeeni M Rajati F, Razzaghi EM. Effectiveness of Relapse Prevention Cognitive Behavioral Model in Opioid - Dependent Patients Participating in the Methadone Maintenance Treatment in Iran. Iranian J Publ Health. 2013;42(8):896-902

67. Sklar SM, Annis HM, Turner NE. Group Comparisons of Coping Self-Efficacy Between Alcohol and Cocaine Abusers Seeking Treatment. Psychol Addict Behav. 1999;13(2):123-33.

68. Abdollahi Z, Taghizadeh F, Hamzehgardeshi Z, Bahramzad O. Relationship between Addiction Relapse and Self-Efficacy Rates in Injection Drug Users Referred to Maintenance Therapy Center of Sari, 1391. Glob J Health Sci. 2014;6(3):138-44. 